\title{
PERAN KEPALA DESA DALAM PEMBERDAYAAN PEREMPUAN MELALUI GERAKAN PKK DI DESA CIHANJUANG
}

\author{
${ }^{1}$ Ashri Bunga Dzikrillah, ${ }^{2}$ Megi Rahma Bungsu, ${ }^{3}$ Wawan Kurniawan \\ 1,2,3IKIP SILIWANGI \\ 1 ashri.bunga@yahoo.com,2megirahmab@gamilcom,3wone1945@gmail.com
}

\begin{abstract}
ABSTRAK
Kemajuan sebuah desa tidak akan terlepas dari keberhasilan seorang pemimpin dalam memimpin daerahnya. Dengan adanya undang-undang tentang desa yang memberikan wewenang kepada kepala desa untuk mengatur daerahnya sendiri sesuai dengan asal usul dan adat istiadat setempat. Salah satu cara yang dilakukan untuk mensejahterakan rakyatnya adalah dengan memanfaatkan organisasi kemasyarakatan salah satunya adalah PKK.Penelitian ini mengangkat permaslahan tentang : Bagaimana peran kepala desa dalam pemberdayaan perempuan melalui gerakan PKK. Permasalahan pokok dalam penelitian ini adalah : (1) Bagaimana peran kepala desa dalam pemberdayaan perempuan melalui gerakan PKK. (2) Bagaimana strategi kepala desa dalam pemberdayaan perempuan melalui gerakan PKK. Teori yang digunakan dalam penelitian ini antara lain, teori kepemimpinan, teori pemberdayaan dan teori organisasi. Metode yang digunakan dalam penelitian ini adalah penelitian kualitatif deskriptif, dengan teknik pengumpulan data wawancara, observasi dan studi dokumentasi. Penelitian ini dilakukan di Desa Cihanjuang Kecamatan Parongpong Kabupaten Bandung Barat. Dengan subyek penelitian sebanyak 6 orang. Hasil dari penelitian ini adalah peran kepala desa menjadi jembatan dengan mitramitra terkait yang bekerja sama dengan PKK, seperti dinas sosial, dinas kesehatan, jumlah kader PKK desa Cihanjuang yang lebih dari 150 adalah hasil dari pemberdyaan perempuan yang dilakukan oleh kepala desa menggunakan seni-seni tertentu. Startegi Kepala desa yaitu memiliki seni tertentu dalam melakukan pendekatan kepada masyarakat, khususnya masyarakat perempuan
\end{abstract}

Kata Kunci: Kepala Desa, PKK, Pemberdayaan

\section{PENDAHULUAN}

Kemajuan sebuah desa tidak akan terlepas dari peran seorang kepala desa dalam memimpin masyarakatnya. Semenjak adanya undang-undang No 22 tahun 1999 mengenai hak otonomi desa, kepala desa memiliki wewenang untuk mengaturdaerah nya sendiri berdasarkan asal-usul dan adat istiadat setempat, dengan demikian kepala desa dapat lebih leluasa untuk mengatur daerah dan masyarakatnya.

Kepala desa memiliki berbagai cara untuk memajukan daerahnya, dapat melalui beberapa organisasi kemasyarakatan yang ada di daerahnya, seperti karang taruna, PKK dan organisasi kemasyarakatan lainnya. Organisasi PKK ada disetiap tingkatan pemerintahan, mulai dari tingkat RW hingga tingkat provinsi, organisasi PKK sering dilibatkan dalam program-program pemerintahan, seperti pemberdayaan dan 
pembangunan. PKK memiliki kepanjangan Pemberdayaan Kesejahteraan Keluarga yang dimana didalmnya tidak hanya tentang pemberdayaan saja, namun bagaimana PKK dapat meningkatkan tingkat kesehatan masyarakat, pendidikan, dan kesejahteraan masyarakat. Berdasarkan peraturan dalam Negeri Republik Indonesia no 1 tahun 2013 tentang pemberdayaan masayarakat melalui gerakan pemberdayaan dan kesejahteraan keluarga, pasal 1 no 5 Gerakan Pemberdayaan dan Kesejahteraan Keluarga adalah gerakan nasional dalam pembangunan masyarakat yang tumbuh dari bawah yang pengelolaannya dari, oleh dan untuk masyarakat menuju terwujudnya keluarga yang beriman dan bertakwa kepada Tuhan yang maha esa, berahlak mulia dan berbudi luhur, sehat sejahtera, maju dan mandiri, kesetaraann dan keadilan gender serta kesadaran hukum dan lingkungan.

PKK memiliki 10 Program Pokok PKK yang meliputi, (1) penghayatan dan pengamalan pancasila, (2) Gotong Royong, (3) Pangan, (4) Sandang, (5) Perumahan dan tata laksana rumah tangga, (6) Pendidikan dan keterampilan, (7) Kesehatan, (8) Pengembangan kehidupan berkoperasi, (9) kelestarian lingkungan hidup,dan (10) Perencanaan sehat. Uraian program pokok PKK dilaksanakan sesuai kondisi dan prioritas kebutuhan masyarakat.

Salah satu cara kepala desa untuk memberdayakan masyarakatnya adalah melalui gerakan PKK, yang dimana lebih berfokus kepada pemberdayaan perempuan. Pemberdayaan perempuan dalam gerakan PKK dimaksudkan untuk meningkatan kesadaran terhadap dirinya. Berdasarkan data Badan Pusat Statisktik Kabupaten Bandung Barat jumlah perempuan pada tahun 2016 berjumlah 804.025 jiwa, namun jumlah tersebut merupakan jumlah perhitungan umum yang artinya tidak dicantumkan berdasarkan usia. Begitu juga jumlah perempuan di Kecamatan Parongpong yang berjumlah 52.213 jiwa. Namun dari data tersebut dapat diambil kesimpulan bahwa potensi kemajuan sebuah desa bisa dengan cara memanfaatkan sumber daya manusia nya, dengan demikian dapat dimaksimalkan potensi yang ada pada masyarakat perempuan.

Banyak pemasalahan yang ditemukan di dalam organisasi PKK, permasalahan tidak hanya bersifat negative namun ada juga yang bersifat positif, di PKK Desa Cihanjuang Kecamatan Parongpong memiliki masalah positif yang spesifik, yaitu jumlah kader PKK Desa Cihanjuang yang berjumlah lebih dari 150 orang, memiliki kampong KB yang menjadi pioneer di kecamatan Parongpong dan program rehabilitasi dan terapi untuk anak-anak penyandang disabilitas. Besarnya peran seorang kepala desa terhadap organisasi PKK, sehingga PKK Desa Cihanjuang meraih banyak prestasi di tingkat kecamatan hingga nasional. Jumlah kader PKK Desa Cihanjuang berjumlah 160 orang, 30 orang diantaranya merupakan kader PKK inti.

Dari latar belakang tersebut penulis tertarik untuk mengadakan penelitian dengan judul

“ Peran Kepala Desa dalam Pemberdayaan Perempuan melalui Gerakan PKK di Desa Cihanjuang" 


\section{KAJIAN TEORI}

\section{A. Teori Kepemimpinan}

Menurut (Rivai, 2007)pemimpin adalah anggota dari suatu kumpulan yang diberi kedudukan tertentu dan diharapkan dapat bertindak sesuai kedudukannya. Seorang pemimpin adalah juga seseorang dalam suatu perkumpulan yang diharapkan dapat menggunakan pengaruhnya untuk mewujudkan dan mencapai tujuan kelompok.

Josephson dan wiraputra dalam (Soetopo, 2010)mengungkapkan pandangannya tentang kepemimpinan sebagai berikut.

1. Kepemimpinan merupakan hasil interaksi antar individu dalam kelompok, bukan suatu yang timbul di atas atau dari status atau kedudukan seseorang. Status dapat meningkatkan atau merusak efektifitas sikap kepemimpinan.

2. Semua anggota mempunyai potensi untuk memimpin dalam memperlihatkan sikap kepemimpinan.

3. Seseorang yang berhasil menjadi pemimpin dalam suatu situasi, belum tentu demikian halnya dalam situasi-situasi yang lain. Dengan demikian kepemimpinan beralih dari situasi ke situasi.

Efektifitas sikap kepemimpinan diukur dengan memperhatikan tujuan, produktivitas dalam mencapai tujuan itu dan solidaritas pembinaan kelompok.

Menurut Nawawi (2010:90) fungsi kepemimpinan yaitu sebagai berikut:

1. Fungsi Instruktif, adalah pemimpin sebagai komunikator yang menentukan apa (isi perintah), bagaimana (cara mengerjakan perintah), bilamana (waktu memulai, melaksanakan dan melaporkan hasilnya), dan dimana (tempat mengerjakan perintah) agar keputusan dapat diwujudkan secara efektif. Sehingga fungsi orang yang dipimpin adalah melaksanakan suatu perintah.

2. Fungsi Konsultatif, adalah pemimpin menggunakan fungsi konsultatif sebagai bentuk dari komunikasi dua arah untuk usaha menetapkan keputusan yang membutuhkan pertimbangan dan konsultasi dengan orang yang dipimpinnya.

3. Fungsi Partisipasi, adalah pemimpin dapat mengaktifkan anggotanya dalam pengambilan keputusan maupun dalam melaksanakannya.

4. Fungsi Delegasi, adalah pemimpin memberikan pelimpahan wewenang yang membuat atau sampai dengan menetapkan keputusan. Fungsi delegasi merupakan kepercayaan seorang pemimpin kepada seorang yang diberikan pelimpahan wewenang untuk bertanggung jawab.

5. Fungsi Pengendalian, adalah pemimpin dapat embimbing mengarahkan, koordinasi dan pengawasan terhadap anktifitas anggotanya.

\section{B. Teori Pemberdayaan}

Menurut (Zubaedi, 2013) pemberdayaan adalah upaya untuk meningkatkan harkat dan martabat golongan masyarakat yang sedang kondisi miskin, sehingga mereka dapat melepaskan dari perangkap kemiskinan dan keterbelakangan. Pemberdayaan mempunyai makna yaitu membuat seseorang dan kelompok berdaya atau dengan kata lain memberikan kekuatan. Sedangkan menurut (Mubarak:2010) pemberdayaan masyarakat dapat diartikan sebagai upaya untuk memulihkan atau meningkatkan kemampuan suatu komunitas untuk mampu berbuat sesuai dengan harkat dan martabat mereka dalam melaksanakan hak-hak dan tanggung jawab selaku anggota masyarakat. Ife (Martono, 2011)mendefinisikan konsep pemberdayaan masyarakat 
sebagai proses menyiapkan masyarakat dengan berbagai sumber daya, kesempatan, pengetahuan, dan keahlian untuk meningkatkan kapasitas diri masyarakat di dalam menentukan masa depan mereka, serta berpartisipasi dan memengaruhi kehidupan dalam komunitas masyarakat itu sendiri. Intinya pemberdayaan masyarakat bertujuan untuk memberikan kekuatan dan kesadaran akan potensi yang dimiliki dan dapat memaksimalkan potensinya tersebut. Menurut (Novian, 2010)pemberdayaan perempuan adalah upaya pemampuan perempuan untuk memperoleh akses dan kontrol terhadap sumber daya, ekonomi, politik, sosial, budaya, agar perempuan dapat mengatur diri dan meningkatkan rasa percaya diri untuk mampu berperan dan berpartisipasi aktif dalam memecahkan masalah, sehingga mampu membangun kemampuan dan konsep diri. Undang-Undang Dasar 1945 yang dijabarkan dalam peraturan perundang-undangan pada asasnya mengandung prinsip persamaan hak an kewajiban bagi laki-laki maupun perempuan tanpa ada perbedaan dalam segala bidang.

\section{Peran PKK dalam PLS}

PKK memiliki kepanjangan Pemberdayaan Kesejahteraan Keluarga, sasarannya PKK adalah memberdayakan masyarakat, memberdayakan masyarakat adalah salah satu hal yang sangat berkaitan dengan PLS, dilihat dari pelaksaanannya, target atau sasaran dan hasil dilakukan dengan pendekatan-pendektan yang ada di PLS, dengan demikian dapat ditarik kesimpulan bahwa PKK merupakan sebuah wadah untuk melaksanakan pemberdayaan, yang dalam pelaksanaannya tidak terikat oleh waktu, target disesuiakn dengan kebutuhan masyarakat, dan kurikulum disesuaikan dengan keadaan mansyarkat. Berdasarkan sejarah PKK, PKK dijadikan kurikulum pendidikan masyarakat karena dinilai program-program kerja PKK dapat meningkatkan kesejahteraan masyarakat. Adanya hubungan antara PKK dengan PLS diantaranya adalah PKK dan PLS memiliki target yang sama yaitu adalah masyarakat, menurut (Mulyono, 2012) secara historis, PNF atau pendidikan non formal memiliki kedudukan yang kuat dalam berbagai jalur birokrasi pemerintahan maupun jalur kehidupan masyrakat lainnya. Secara garis besar dalam proses pelaksanaan program-program di dalam organisasi PKK terdapat proses belajar mengajar secara non formal, menurut (AlB, Februari 2012) proses pembelajaran adalah satu pola untuk mentransformasikan ilmu dari pendidik kepada peserta didik yang didalamnya mencakup mempersiapkan bahan peljaran, mempersiapkan media pembelajaran, membahas materi belajar, prosedur pembelajaran serta memecahkan masalah bersama antara peserta didik dan pendidik.

\section{METODE PENELITIAN \\ Metode Penelitian}

Pendekatan yang gunakan dalam penelitian ini adalah pendekatan kualitatif. Melalui pendekatan ini di harapkan peneliti dapat menghasilkan data yang bersifat deskriptif guna mengungkapkan sebab dan bagaimana proses terjadinya saat di lapangan.

Metode yang digunakan dalam metode kualitatif adalah wawancara dan observasi (Sugiyono, 2014). Wawancara dilakukan oleh peneliti melalui tatap muka dengan narasumber, pelaksanaan wawancara terbagi dalam tiga tahap yaitu persiapan, pelaksanaan dan tutup. Observasi adalah proses pengamatan suatu peristiwa dengan cara mencatat data atau dengan mendapatkan informasi secara sistematis.

Instrument penelitian atau alat yang digunakan saat proses penelitian berlangsung adalah pedoman wawancara yang didalamnya terdiri dari beberapa pertanyaan, 
handphone, alat tulis seperti pulpen atau pensil, buku, kamera. Penelitian ini dilakukan di Desa Cihanjuang, Kecamatan Parongpong Kabupaten Bandung Barat

\section{HASIL DAN PEMBAHASAN}

\section{A. Hasil}

Berdasarkan penelitian yang dilakukan, ditemuka hasil sebagai berikut :

1. Kepala Desa selalu memberikan motivasi kepada kader-kader PKK, karena kepala desa dinilai sangat ramah kepada masyarakat. Selain itu kepala desa selalu memantau kegiatan PKK secara langsung atau tidak langsung, salah satu contoh cara tidak langsung adalah memalui aplikasi whats app.

2. Mengenai program-program yang ada di PKK disesuaikan dengan kebutuhan masyarakat, dalam hal menganalisi kebutuhan masyarakat, kepala desa tidak bekerja sendirian namun melibatkan banyak pihak salah satunya adalah PKK.

\section{B. Pembahasan}

Sesuai dengan hasil penelitian yang dilakukan peneliti mengenai peran Kepala Desa dalam pemberdayaan perempuan melalui gerakan PKK, ditemukan bahwa dengan adanya jumlah kader PKK yang lebih dari 150 orang adalah salah satu hasil dari pemberdayaan yang dilakukan Kepala Desa kepada masyarakat, masyarakat yang terlibat dalam kepengurusan dan keanggotaan PKK hamper semuanya adalah perempuan. Seni pendekatan yang dilakukan oleh kepala desa menghasilkan hasil yang cukup baik, diantaranya meningkatnya antusias masyarakat sehingga mau berpartisipasi dengan menjadi kader PKK secara suka rela. Kerjasama antara kepala desa dengan ketua tim penggerak PKK yang menjadi penguat sebuah keberhasilan sebuah program, peran kepala desa sebagai jembatan dengan mitra terkait yang bekerja sama dengan PKK menjadikan PKK Desa Cihanjuang merasa terfasilitasi, sehingga kader-kader PKK merasa lebih antusias dalam menjalankan setiap program. Dalam pelaksanaanya Kepala Desa melakukan secara tidak langsung melakukan berbagai tahapan seperti perencanaan, pengorganisasian, penggerakan, pembinaan, penilaian dan pengembangan.

Menurut pendapat (Suriningrat, 2001) Kepala Desa adalah penguasa tunggal didalam pemerintahan desa, bersama-sama dengan pembantunya dan ia merupakan pamong desa dalam pelaksanaan penyelenggaraan urusan rumah tangga desa, disamping itu dia menyelenggarakan urusan-urusan pemerintahan. Menurut (Sudjana, 2010) dalam pendidikan luar sekolah untuk menjalankan sebuah program pendidikan luar sekolah ada fungsi manajemen yang terdiri atas enam fungsi yang berurutan, keenam fungsi tersebut adalah:

\section{1) Perencanaan}

Perencanaan mencakup rangkaian kegiatan untuk menentukan tujuan umum, tujuan khusus suatu organisasi atau lembaga penyelenggara non formal, berdasarkan dukungan informasi yang lengkap. Perencanaan berkaitan dengan penyususnan rangkaian kegiatan untuk mencapai tujuan lembaga penyelenggara pendidikan non formal. 
2) Pengorganisasian

Pengorganisasian adalah kegiatan mengidentifikasi dan memadukan sumbersumber yang diperlukan ke dalam kegiatan yang akan dilakukan dalam mencapai tujuan yang telah ditetapkan.

3) Penggerakan

Penggerkan ialah untuk mewujudkan tingkat penampilan dan partisipasi yang tinggi dari setiap pelaksanaan yang terlibat dalam kegiatan untuk mencapai tujuan yang telah ditetapkan.

4) Pembinaan

Pembinaan adalah upaya untuk memelihara efisiensi dan efektifitas kegiatan sesuai dengan yang telah direncanakan dengan uapaya mencapai tujuan yang telah ditetapkan. Pembinaan diselenggarakan melalui pendekatan langsung dan tak langsung. Pendekatan langsung dilakukan oleh pengelola terhadap paara penyelenggara dan pelaksana program kegiatan pendidikan. Pendekatan tidak langsung dilakukan melalui staf atau pihak lain yang berkaitan dengan tugas para penyelenggara dan pelaksana.

5) Penilaian

Penilaian berperan untuk menghimpun, mengolah, dan menyajikan informasi untuk mengambil keputusan yang menyangkut upaya justifikasi, perbaikan, penyesuaian, dan pengembangan pendidikan nonformal.

6) Pengembangan

Pada dasarnya pengembangan adalah pelaksanaan kembali program pendidikan nonformal melalui fungsi-fungsi manajemen yang telah dikemukakan sebelumnya, dimuali dari perencanaan, pengorganisasian, penggerakan, pembinaan, penilaian sampai dengan pengembangan. Dengan kata lain pengembangan berperan untuk menjebatani siklus kegiatan pendidikan nonformal dalam rantai peningkatan kegiatan secara berkelanjutan.

\section{PENUTUP}

\section{A. Kesimpulan}

Peran Kepala Desa dalam pemberdayaan perempuan di Desa Cihanjuang sangatlah besar, Kepala Desa menjadi jembatan dengan mitra-mitra terkait yang bekerja sama dengan PKK Desa Cihanjuang, dalam pelaksananya Kepala Desa selalu memberikan arahan baik secara langsung dan tidak langsung, mengawasi dan mengevalusi setiap kegiatan PKK yang berlangsnung, secara langsung dan tidak langsung. Jumlah anggota PKK yang berjumlah lebih dari 150 orang, merupakan hasil dari pemberdayaan yang dilakukan oleh Kepla Desa kepada masyarakat, dengan seni dan teknik tertentu dalam mekakukan pendekatan kepada msyarakat sehingga banyak maysrakat khususnya perempuan untuk berpartisipasi menjadi kader PKK secara suka rela. Kepala Desa berusaha memfasilitasi kebutuhan-kebutuhan yang dibutuhkan oleh kader-kader PKK, hal tersebut juga yang membuat kader-kader PKK semakin bersemangat.

Strategi Kepala Desa dalam pemberdayaan perempuan dilakukan dengan cara pendekatan kepada masyarakat menggunakan seni tertentu yang disesuaikan dengan karakteristik masyarakatnya, selain itu kepala desa melakukan pembinaaan dan 
pengarahan secra tidak langsung memalui ketua tum penggerak PKK yang tidak lain adalah istri kepala desa, dengan demikian arahan dan pembinaan yang dilakukan dapat lebih intensif, setelah itu tim penggerak PKK menyampaikan kembali kepada kaderkader PKK dengan tehnik dan caranya sendiri. Kader-kader PKK selalu berantusias dalam setiap kegiatan yang ada di PKK, mau mengikuti arahan-arahan yang diberikan dan berantusias untuk bersma-sma dalam melalkukan kemajuan dan kesejahteraan masyarakat.

\section{B. Saran}

Berdasarkan penelitian, maka peneliti memberikan saran sebagai berikut :

1. Kepala Desa dapat lebih melakukan pembinaan secara langsung, agar rasa persaudaraan dengan kader-kader PKK menjadi lebih kuat.

2. Berbagai cara untuk menjalin silaturahmi salah atunya adalah diadakannya makan bersama, dan Kepala Desa beserta staf bisa ikut terlibat, untuk menjalin silaturahmi dan pembinaan akan lebih santai dilakukan oleh Kepala Desa

3. PKK Desa Cihanjuang dapat mengadakan pertemuan rutin dengan PKK desa lainnya, seperti PKK Desa Cihanjuang Rahayu, PKK Desa Sariwangi, PKK Desa Mekarwangi yang dapat saling bekerjasama untuk meningkatkan kesejahteraan masyarakt secara bersama-sama.

\section{DAFTAR PUSTAKA}

Al-B, A. (Februari 2012). PROSES PEMBELAJARAN PENDIDIKAN KEAKSARAAN BERBASIS KELUARGA DI PISAT KEGIATAN BELAJAR MASYARAKAT KANDAGA DESA MAYANG KECAMATAN CISALAK KABUPATEN SUBANG. Empowerment Jurnal Ilmiah Program Studi Pendidikan Luar Sekolah STKIP Siliwangi Bandung, Vol 1, No 1, 53.

Martono, N. (2011). Sosiologi Perubahan Sosial: Perspektif Klasik, Modern, Posmodern, dan Poskolonial. Jakarta: Rajawali Press.

Mulyono, D. (2012). MENEGASKAN KARAKTER PENDIDIKAN NONFORMAL. Jurnal Ilmiah Program Studi Pendidikan Luar Sekolah STKIP Siliwangi Bandung, Vol 1, No 1,66 .

Novian, B. (2010). Sekilas tentang Pemberdayaan Perempuan. Artikel Sanggar Kegiatan Belajar Kota Pangkal Pinang.

Rivai, V. (2007). Kepemimpinan dan Prilaku Organisasi. Jakarta: PT.Raja Gravindo. Soetopo, H. (2010). Perilaku Organisasi Teori dan Praktik di Bidang Pendidikan. Bandung: PT Remaja Rosdakarya Offset.

Sudjana, D. (2010). Manajemen Program Pendidikan untuk Pendidikan Nonformal. Bandung : Falah Production.

Sugiyono. (2014). Metode Penelitian Kuantitatif, Kualitatif, dan R\&D. Bandung: Alfa Beta.

Suriningrat, B. (2001). Pemerintahan dan Administrasi. Bandung: PT. Mekar Djaya. Zubaedi. (2013). PENGEMBANGAN MASYARAKAT : Wacana dan Praktik. Jakarta: KENCANA PRENADA MEDIA GROUP. 